\title{
The Hardness and Microstructure of The Modified 13Cr Steam Turbine Blade Steel in Tempered Conditions
}

\author{
Siska Prifiharni ${ }^{\# 1}$, Hadi Perdana ${ }^{* 2}$, Toni B. Romijarso ${ }^{\# 3}$, Bintang Adjiantoro ${ }^{\# 4}$, Andinnie Juniarsih ${ }^{* 5}$, \\ Efendi Mabruri ${ }^{\sharp 6}$ \\ ${ }^{\#}$ Research Center for Metallurgy and Material, Indonesian Institute of Science \\ Kawasan Puspiptek Gedung 470, Tangerang, Indonesia \\ ${ }^{1}$ sisk002@lipi.go.id \\ 6effe004@lipi.go.id \\ *Metallurgical Engineering, University of Sultan Ageng Tirtayasa \\ Jl. Jend. Sudirman Km. 3, Cilegon, Indonesia
}

\begin{abstract}
Martensitic stainless steels were usually used for turbine blade. Their properties can be improved in various ways, such as by heat treatment. This paper reports the influences of tempering temperature on hardness and microstructure of the modified $13 \mathrm{Cr}$ martensitic stainless steels. Samples were austenitized at $1050^{\circ} \mathrm{C}$ and tempered at $300,400,500,550,600,650$, and $700^{\circ} \mathrm{C}$. Hardness measurement was conducted by Rockwell $\mathrm{C}$ indentation and metallographic observation was conducted by scanning electron microscope (SEM). The results show that increasing tempering temperature until $500^{\circ} \mathrm{C}$ can improve hardness. The microstructure formed consists of tempered martensite containing carbides $\mathbf{M}_{23} \mathrm{C}_{6}$. The presence of carbides can also increasing hardness. Increasing tempering temperaturefrom $500^{\circ} \mathrm{C}$ to $650^{\circ} \mathrm{C}$ can decrease $\mathrm{Cr}$ content of carbide.
\end{abstract}

Keyword-Steam turbine blade, Martensitic stainless steel, Carbide

\section{INTRODUCTION}

Martensitic stainless steels were commonly used for manufacturing component due to their high mechanical properties and moderate corrosion resistance, operating at either high or low temperature. Due to their properties could be improved by heat treatment, these steels are suitable for various application such as turbine blade [1][3]. However, the failure of the blade frequently found in service due to mechanical and environmental interaction which operated in turbine system. Furthermore, almost 50\% the failures of turbine blade are related to fatigue, pitting corrosion, stress corrosion cracking, and corrosion fatigue [4].

The mechanical properties and corrosion resistance of martensitic stainless steels depend on chemical composition and heat treatment. Heat treatment process of these steels commonly involved solid-solution treatment (ausenitizing) to form an austenite structure, and dissolving carbides, followed by cooling or quenching to transform austenite into martensite structure, and then followed by tempering to obtain carbide precipitation [5]. The amount of carbide can affect mechanical properties and corrosion resistance in this material. The presence of retained austenite may affect wear resistance, fatigue properties, and ductility [6].

The addition of small increase Molybdenum (Mo) and Nickel (Ni) in stainless steel can contribute to increase corrosion resistance. Mo is particularly effective to increase corrosion resistance, but only in presence of Chromium (Cr). Various explanations have been reported for the effect of Mo to increase corrosion resistance $[7,8]$. The modified $13 \mathrm{Cr}$ martensitic stainless steel containing $\mathrm{Ni}$ and Mo are being developed in our laboratory [9]. This study reports on the hardness and microstructure of the modified 13Cr3Ni3Mo martensitic stainless steel with respect to tempering temperature.

\section{EXPERimental Procedure}

The modified 13Cr martensitic stainless steel ingot was prepared in electric induction furnace. The ingots of $5 \times 5 \times 10 \mathrm{~cm}$ in dimension were hot forged at around $900-1100^{\circ} \mathrm{C}$ until the dimension of the ingots decreased to about $12 \times 6 \times 2 \mathrm{~cm}$. The square specimens of $1 \mathrm{~cm}^{2}$ in thickness were cut from forged alloys for chemical composition test using Optical Emission Spectrometer (OES). The chemical composition of the alloys is presented in Table 1 . The specimens were austenitized at $1050^{\circ} \mathrm{C}$ for 1 hour followed by oil quench to obtain martensite structure. Then, specimens were tempered at 300, 400, 500, 550, 600, 650, and $700^{\circ} \mathrm{C}$ for 1 hour. Rockwell hardness measured on all heat treated samples using hardness Rockwell C scale with load $150 \mathrm{kgf}$ at room temperature. For metallographic test samples were polished and etched using kalling's reagent, then examined using scanning electron microscope (SEM). Energy dispersive X-ray spectroscopy (EDS) analysis was utilized to identify carbides during tempering. 
TABLE I. Chemical composition in \%wt of the modified 13Cr martensitic stainless steel in this study

\begin{tabular}{|r|c|c|c|c|c|c|c|c|c|}
\hline Steel Type & C & S & P & Mn & Si & Cr & Mo & Ni & Fe \\
\hline 13Cr3Mo3Ni & 0.10 & 0.005 & 0.02 & 0.61 & 0.24 & 12.73 & 2.52 & 2.93 & Bal. \\
\hline
\end{tabular}

\section{Results AND Discussion}

The effect of tempering temperature of the 13Cr modified martensitic stainless steel on hardness value is shown in Fig.1. As seen, hardness decreased from as-quenched until tempering temperature at $400^{\circ} \mathrm{C}$. The initial drop in hardness is due to precipitation of M3C which causes softening of the martensite because of the carbon depletion [10]. Hardness was almost constant for tempering temperature 500 to $600^{\circ} \mathrm{C}$. It can be observed from Fig. 1 that the highest hardness of $13 \mathrm{Cr} 3 N i 3 M o$ martensitic stainless steel in temper condition is 50.6 HRC at $500^{\circ} \mathrm{C}$. Hardness increase in the range of tempering temperature 400 to $500^{\circ} \mathrm{C}$. The increasing of hardness in the range of 400 to $500^{\circ} \mathrm{C}$ can be attributed to secondary hardening phenomenon. This phenomenon can be related to formation of $\mathrm{M}_{7} \mathrm{C}_{3}$ carbides within the martensite lath. It can be also seen in Fig.1 that hardness decrease with the increase at tempering temperature in range 500 to $700^{\circ} \mathrm{C}$. It can occur due to the $\mathrm{M}_{7} \mathrm{C}_{3}$ carbides started to coarsen and partially transform to $\mathrm{M}_{23} \mathrm{C}_{6}$ carbides [1]. The reason for variation in properties can be attributed to combined effect of (i) hardening: due to transformation of retained austenite and formation of fine precipitates; and (ii) softening: due to reduction in internal stresses, decrease in dislocation density within martensite lath, and formation of reversed austenite as described in other report [11]. The increase hardness of the modified $13 \mathrm{Cr}$ stainless steel is also due to presence of tempered martensite. While tempering at higher temperatures, quenched martensite formed while solution annealing starts softening which leads to elimination of internal stresses, decrease in dislocation density, and occurrence of retained austenite [12].

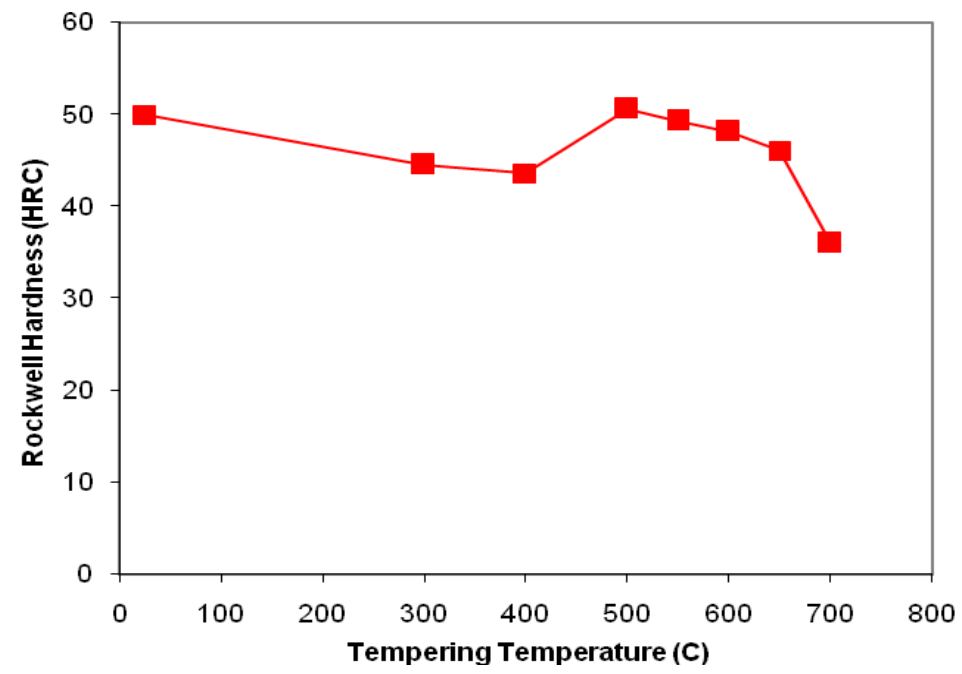

Fig 1. The hardness of the modified 13Cr martensitic stainless steel at various tempering temperature.

Fig. 2 shows SEM microstructure of various tempering temperature at as-quenched, 400,500 , and $650^{\circ} \mathrm{C}$. It can be observed that the microstructure of tempered stainless steel generally contain martensite lath, and carbide. Carbide formed at tempering temperature of $400^{\circ} \mathrm{C}$ is not so clear to see. However, when tempering temperature reach 500 and $650^{\circ} \mathrm{C}$ carbide are so clear. The EDS analysis of carbide on the modified $13 \mathrm{Cr}$ martensitic stainless steel shows the dominant peak of Cr and Fe. For Mo show small peak compared with the others, but higher than the steel matrix (Fig. 3). Table 2 shows chromium content for both tempering temperature is about $30-34 \%$ Cr that can be defined as $\mathrm{M}_{23} \mathrm{C}_{6}$ carbide. The formation of carbide $\mathrm{M}_{23} \mathrm{C}_{6}$ at tempering temperature $500^{\circ} \mathrm{C}$ has been investigated [13]. At low tempering temperature, the formation of carbide is unstable $M_{3} C$ that will be transformed into stable carbide $M_{7} C_{3}$ and $M_{23} C_{6}$ at higher temperatures. These transformations could contribute to the secondary hardening, before the final softening produced by the coarsening of the most stable carbides [10]. 

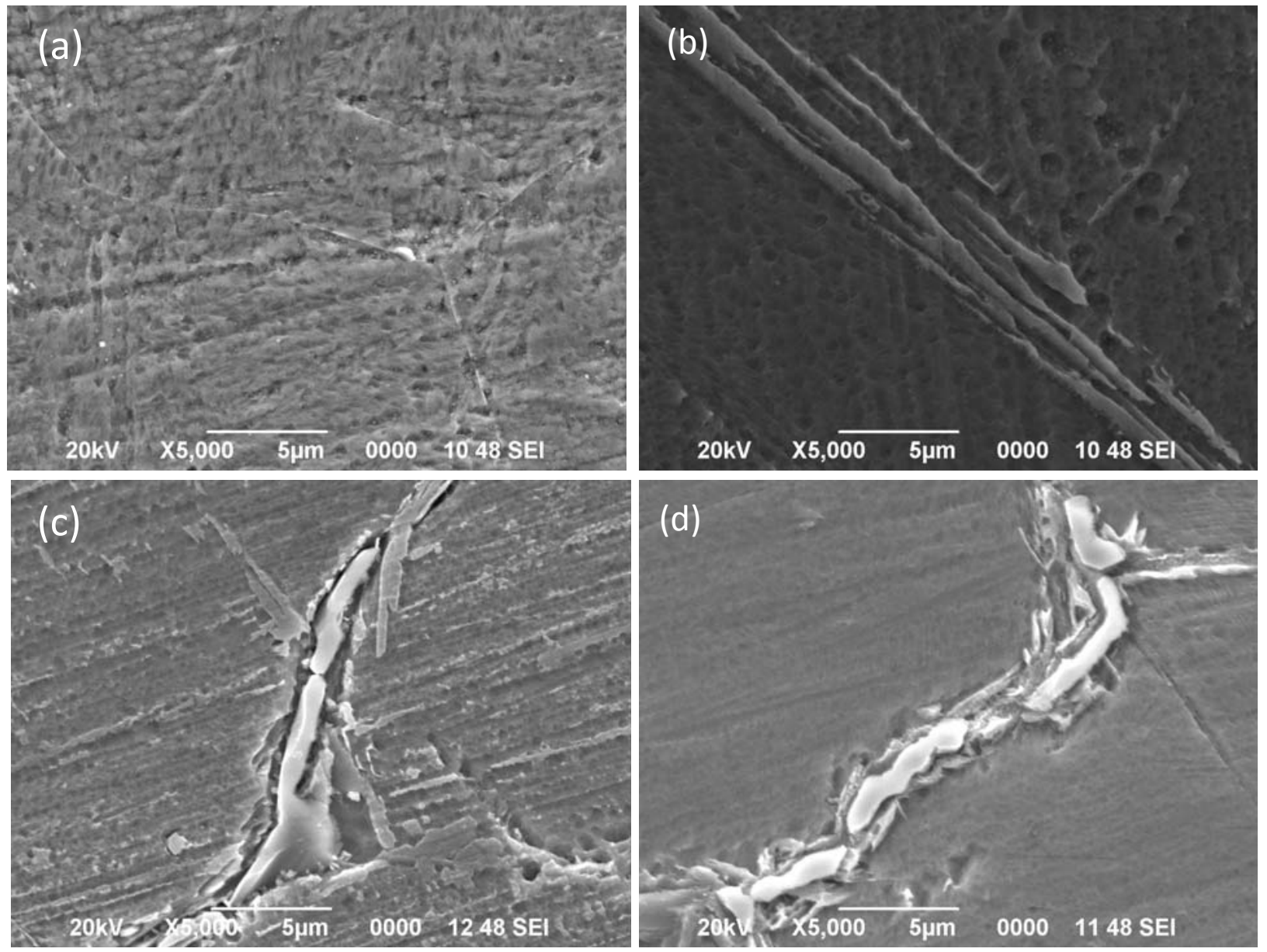

Fig. 2 SEM micrograph of specimens tempered at (a) as-quenched, (b) $400^{\circ} \mathrm{C}$, (c) $500^{\circ} \mathrm{C}$, and (d) $650^{\circ} \mathrm{C}$.
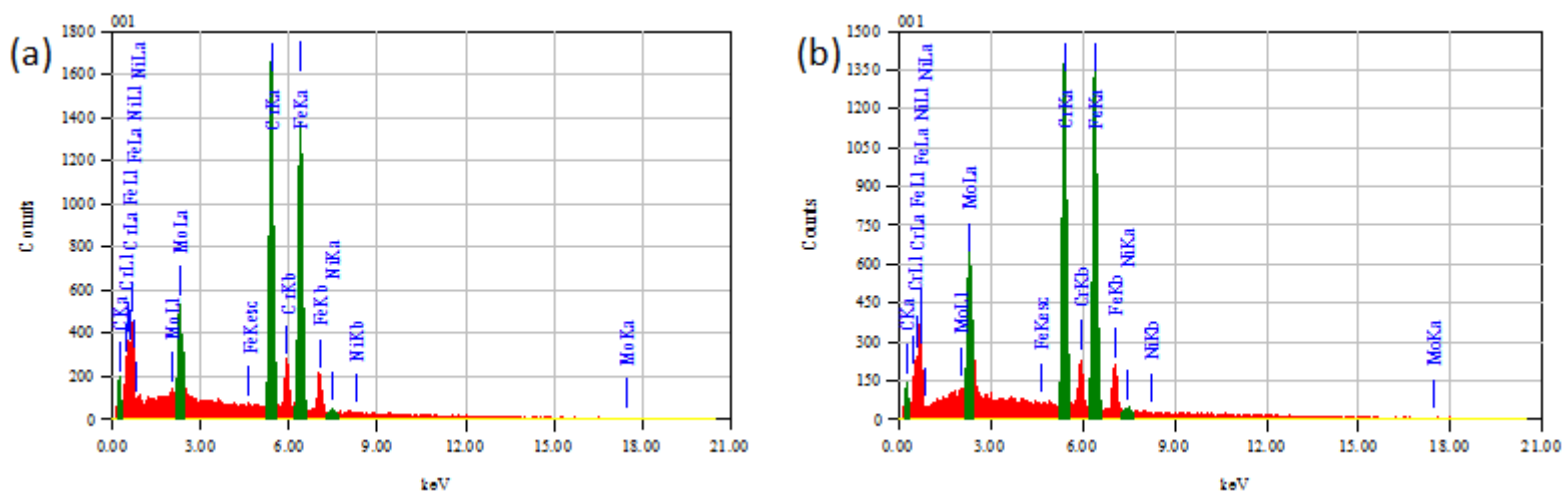

Fig. 3 EDS analysis of specimens tempered at (a) $500^{\circ} \mathrm{C}$, (b) $650^{\circ} \mathrm{C}$.

The addition of Mo in the modified $13 \mathrm{Cr}$ martensitic stainless steel can be attributed to increase $\delta$-ferrite phase content into microstructure. However, $\delta$-ferrite phase content can be decreased by the addition of Ni into the steel. The formation of $\delta$-ferrite in the $13 \mathrm{Cr}$ modified martensitic stainless steel have been investigated in previous report [14].

TABLE II. Chemical compositions of carbide in the modified 13Cr martensitic stainless steel at various tempering temperature

\begin{tabular}{|c|l|l|l|l|r|}
\hline Temperature $\left({ }^{\circ} \mathbf{C}\right)$ & \multicolumn{1}{|c|}{$\mathbf{C}$} & \multicolumn{1}{|c|}{$\mathbf{C r}$} & \multicolumn{1}{|c|}{ Mo } & \multicolumn{1}{c|}{$\mathbf{~ i ~}$} & Fe \\
\hline 500 & 5.8 & 34.90 & 9.23 & 1.45 & 48.62 \\
\hline 650 & 4.93 & 30.95 & 11.04 & 0.73 & 52.34 \\
\hline
\end{tabular}




\section{CONCLUSION}

The tempering temperature could strongly affect the hardness and microstructure of the modified $13 \mathrm{Cr}$ martensitic stainless steel. Increasing tempering temperature can improve the hardness of modified $13 \mathrm{Cr}$ martensitic stainless steel. The highest hardness obtained at $500^{\circ} \mathrm{C}$. Increase hardness can be attribute to formation of precipitation carbide $\mathrm{M}_{23} \mathrm{C}_{6}$ into microstructure. Increasing tempering temperature from 500 to $650^{\circ} \mathrm{C}$ can decreased $\mathrm{Cr}$ content on carbide and increase Mo content on carbide.

\section{ACKNOWLEDGMENT}

This paper is part of development of high temperature material for power plant research. The authors would like to be obliged to Research Center for Metallurgy and Material of Indonesian Institute of Sciences for providing laboratory facility and funding this research.

\section{REFERENCES}

[1] A. N. Isfahany, H. Saghafian, and G. Borhani, "The effect of heat treatment on mechanical properties and corrosion behavior of AISI420 martensitic stainless steel,” J. Alloys Compd., vol. 509, no. 9, pp. 3931-3936, 2011.

[2] G. Chakraboty, C. . Das, S. K. Albert, A. . Bhaduri, V. T. Paul, G. Panneerselvam, and A. Dasgupta, "Study on tempering behaviour of AISI 410 stainless steel,” Mater. Charact., vol. 100, no. January 2016, pp. 81-87, 2015.

[3] I. Taji, M. H. Moayed, and M. Mirjalili, "Correlation between sensitisation and pitting corrosion of AISI 403 martensitic stainless steel," Corros. Sci., 2015.

[4] D. Ziegler, M. Puccinelli, B. Bergallo, and A. Picasso, "Investigation of turbine blade failure in a thermal power plant," Case Stud. Eng. Fail. Anal., vol. 1, no. 3, pp. 192-199, 2013.

[5] L. D. Barlow and M. Du Toit, "Effect of the austenitising heat treatment on the microstructure and hardness of martensitic stainless steel AISI 420,” J. Mater. Eng. Perform., vol. 21, pp. 1327-1336, 2012.

[6] J. Y. Park and Y. S. Park, "The effects of heat-treatment parameters on corrosion resistance and phase transformations of 14Cr-3Mo martensitic stainless steel,” Mater. Sci. Eng. A, vol. 448-451, pp. 1131-1134, 2007.

[7] G. S. Frankel, "Pitting Corrosion of Metals A Review of the Critical Factors," J. Electrochem. Soc., vol. 145, no. 6, pp. 2186-2198, 1998.

[8] X. Lei, Y. Feng, J. Zhang, A. Fu, C. Yin, and D. D. Macdonald, "Impact of Reversed Austenite on the Pitting Corrosion Behavior of Super," Electrochim. Acta, 2016.

[9] E. Mabruri, M. S. Anwar, S. Prifiharni, T. B. Romijarso, B. Adjiantoro, E. Mabruri, M. S. Anwar, and S. Prifiharni, “Tensile Properties of the Modified 13Cr Martensitic Stainless Steels,” in AIP Conference Proceedings, 2016, vol. 020039, pp. 0-5.

[10] K. P. Balan, A. V. Reddy, and D. S. Sarma, “Austenite Prepcipitaion During Tempering In 16Cr-2Ni Martensitic Stainless Steels,” Scr. Mater., vol. 39, no. 7, pp. 901-905, 1998.

[11] C. Krishna, N. Kumar, A. K. Jha, B. Pant, and K. M. George, “Microstructure and Properties of 15Cr-5Ni-1Mo-1W,” Steel Reasearch, vol. 86, no. 1, pp. 51-57, 2015.

[12] Z. Dening, H. Ying, Z. Wei, and F. Xudong, "Influence of Tempering Process on Mechanical Properties of 00Cr13Ni4Mo Supermartensitic Stainless Steel,” J. Iron Steel Researvh, vol. 17, no. 8, pp. 50-54, 2010.

[13] S. Lu, K. Yao, Y. Chen, M. Wang, X. Liu, and X. Ge, "The effect of tempering temperature on the microstructure and electrochemical properties of a 13 wt .\% Cr-type martensitic stainless steel,” Electrochim. Acta, vol. 165, pp. 45-55, 2015.

[14] E. Mabruri, M. S. Anwar, S. Prifiharni, T. B. Romijarso, and B. Adjiantoro, "Pengaruh Mo dan Ni Terhadap Struktur Mikro dan Kekerasan Baja Tahan Karat Martensitik 13Cr,” Maj. Metal., vol. 3, pp. 133-140, 2015.

\section{Author Profile}

Siska Prifiharni Researcher at Research Centre for Metallurgy and Material, Indonesian Institute of Science

Hadi Perdana Univerisy Student at Metallurgical Engineering, University of Sultan Ageng Tirtayasa

Toni B Romijarso Researcher at Research Centre for Metallurgy and Material, Indonesian Institute of Science

Bintang Adjiantoro Researcher at Research Centre for Metallurgy and Material, Indonesian Institute of Science

Andinnie Juniarsih Lecturer at Metallurgical Engineering, University of Sultan Ageng Tirtayasa

Efendi Mabruri Researcher at Research Centre for Metallurgy and Material, Indonesian Institute of Science 